\title{
The Indigenous Poetry of Resistance by the Colombian Poet Fredy Chikangana: A Transitivity Systemic Analysis
}

\author{
Sthephanny Moncada Linares², Xin Zhi-Ying ${ }^{2}$ \\ ${ }^{1}$ Xiamen University, China. e-mail: sthephannyml@outlook.com \\ ${ }^{2}$ Xiamen University, China. e-mail: xinzhiying@xmu.edu.cn
}

\begin{tabular}{|c|c|}
\hline ARTICLE INFO & ABSTRACT \\
\hline $\begin{array}{l}\text { Keywords: } \\
\text { experiential meaning, } \\
\text { functional linguistics, } \\
\text { indigenous poetry, } \\
\text { oralitura, resistance }\end{array}$ & $\begin{array}{l}\text { The emergence of Indigenous poetry to the public domain has represented a } \\
\text { milestone in their struggle to voice their communities' past and present } \\
\text { experiences despite the ongoing ostracizing discourses from societies as the } \\
\text { ones residing in Indo-America. In this sense, the present paper will offer an } \\
\text { analysis of selected poetry by the Colombian indigenous poet Fredy } \\
\text { Chikangana in the light of the transitivity system informed by the Systemic } \\
\text { Functional Linguistics theory to unveil their experiential meaning construal. } \\
\text { To attain this goal, a descriptive quantitative and qualitative research method } \\
\text { approach was applied through which the different process types, participants, } \\
\text { and circumstances arising from the corpus were systematically identified, } \\
\text { calculated, and analyzed. Findings indicated that among the six transitivity } \\
\text { process types, the material processes ( } 47 \% \text { ) dominated his poems, followed } \\
\text { by the relational realizations (27\%) whereas the verbal, behavioral, } \\
\text { existential, and mental processes were relatively low altogether, representing } \\
\text { an overall occurrence of } 26 \% \text {. This reveals that the author's primary goal was } \\
\text { to employ poetry as an agentive act of resistance that originated from the } \\
\text { context of the situation in which his Yanakuna community has been and is } \\
\text { immersed. }\end{array}$ \\
\hline \multicolumn{2}{|c|}{$\begin{array}{l}\text { How to cite: } \\
\text { Linares, S. M. \& Zhi-Ying, X. (2021). The Indigenous Poetry of Resistance by the Colombian Poet Fredy } \\
\text { Chikangana: A Transitivity Systemic Analysis. Indonesian Journal of English Language Teaching and } \\
\text { Applied Linguistics, 5(2), 401-416 }\end{array}$} \\
\hline
\end{tabular}

\section{Introduction}

As an aesthetic and creative phenomenon existing within civilizations, poetry has been highly appreciated for its potentiality to represent humans' inner and outer world experiences. Research seeking to unveil the hidden messages encoded within poems has been extensively conducted mainly on the works of white people as they remain undoubtedly on top of the existing mainstream institutional hierarchies (Sims \& Lea, 2008). However, few studies have focused on those compositions generated by minority groups like the indigenous since there is still a predominant aesthetic criterion and long-existent colonialism mindset that judges literary production from subaltern collectives as exotic and barely elaborated (Barragán, 
2016; Fernández, 2009) and therefore, not worthy of appreciation and interpretation. To tackle this need, the present work aims to analyze the lexico-grammar choices employed by the Colombian indigenous poet Fredy Chikangana in five of his poems to discover their construal of experiential meaning.

Over time, the literature has shown that the level of representation of Indigenous works across cultures is less recognized and less widely available as aborigines seem to face more obstacles when occupying academic spaces established on the violent historical grounds of modernity (Ahenakew, 2016). Regardless of its socio-cultural, aesthetic, and linguistic value, their literary production has been traditionally situated in an inferior and peripheral status, overlooked by history, educational institutions, and even the mainstream market in a pursue to suppress their truths (Abt, 2008) and consequently, their identity as individuals and community. Nonetheless and despite this sense of racial discrimination and inequality, indigenous voices and epistemologies have been undiscouraged and continue raising to the public sphere as demonstrated by the contemporary poet Fredy Chikangana, whose poetry and social activist efforts have placed him as one of the Latin-American writers "with the greatest circulation and, for want of a better word, prestige" (Ferreira, 2018).

Fredy Chikangana or Wiñay Mallki (i.e., indigenous name meaning 'rooted in time') was born in the Yanakuna Mitmak community settle down in South-East Cauca, Colombia. He belongs to the first visible generation of Colombian indigenous writers (Rocha, 2013) and selfproclaimed as an orator (i.e., mitmak or oralitor) or archeologist of the word, whose mission is to navigate the oral narratives of his community by digging into their memories to generate new stories in his compositions (Camelo, 2017). His poetry, nationally and internationally published in journals and newspapers, includes Bird spirit (Espíritu de pájaro), Handful of Earth (Puñado de Tierra), Footprints (Huellas), The stone of water (La piedra del agua), Under the Earth (Bajo Tierra), A word from Grandfather (Palabra de Abuelo), The teaching of the Sun (Enseñanza del Sol), being the last five poems his most representative ones and the corpus of analysis of this document. His repertoire is built on a mythic vision of his territory and his understanding of the Cosmo, this latter composed of three planes of existence, the matter world (i.e., for human beings, animals and plants, subjects that possess supernatural characteristics), the up-world (i.e., for the almighty), and the down-world (i.e., for the dead).

As it can be seen in Chikangana's writings, poetry is one of the most impressive, beautiful, and widely effective modes of expression (Mathew Arnold, 1822-1888), capable of bringing to life an overflow of images, sentiments, and thoughts. It is a feeling confessing itself to itself (John Stuart Mill, 1806-1873), a way of knowing (Hughes, 2007). At last, it is a commitment to the essence of life as we name the world, create and recreate it (Chikangana cited by Rodríguez, 2019). Unlike any other literary works, the majesty of poetry realized through its figurative language and non-linear and non-literal composition requires a greater inferential demand to construe its true meaning (Peskin, 1998), this is why it has been increasingly investigated from the Systemic Functional Linguistics (hereafter referred to as SFL) and particularly, from its Transitivity system. This theoretical approach serves as a discourse analysis tool to elucidate the way meaning is signified by the writer and how it portrays his/her worldviews through the social function of the world-structures (Halliday, 1985; Halliday, 1994; Halliday \& Matthiessen, 2004). 
An illustration of the aforementioned is the transitivity analysis of Les Murray's poem 'Widower in the Country' by Hasan (1985), one of the most recognized and influential SFL scholars. She explained how the author's lexico-grammar choices constructed the representation of the protagonist, a man, as grieving his lost wife. Similarly, Hassanpour and Hashim (2012a) analyzed the ideational meaning behind the poem 'Green Delusion' by the Iranian poet Forough Farrokhzad. Their findings indicated that the participant, a female persona, was mainly depicted in a constant struggle to find her subjectivity outside her traditional homemaking role as mother and wife, a scenario enacted through the use of several negative-loaded adjectives (e.g., cramped, alone, sunless), negative material processes (e.g., I could not anymore, I could not), words that connote women's domain (e.g., laundry, kitchen), among some other linguistic resources. For her part, Larbaoui (2019) observed that the Ugandan poet Okot p'Bitek employed the 'Song of Lawino' poem to describe, from a post-colonial approach, the identity of Africans by differentiating them from Western people based on categories like religion, education, politics, art, time value, beauty care, and emotional expression. Thus, for example, he employed the adjective 'clever' to make a comparison with white men and referred to the behavioral verb 'to dance' to depict the way they dance silently. Other research works of this type also include Boer et al. (2018); Damanik (2018); Hassanpour and Hashim (2012b); Ogungbemi (2016); Zuhud and Afrianto (2014), to name but a few.

In this line of thought and with the purpose to contribute to the theoretical-practical study of indigenous poetry, the analysis of the five selected poems is presented below. Hence, this manuscript first provides a general overview of the supporting theory, it then offers a description of the followed methodology, and finally, displays the findings along with a discussion and a concluding remark.

\section{Literature Review}

\subsection{A Systemic Functional Perspective on Language}

Language has been so far the most researched and arguably best understood semiotic resource as being deemed to be the highest and most complex of all, and from which a socialtheoretical model of experience known as Systemic Functional Linguistics was developed. SFL's main principle holds that language is the primary resource for meaning-making resulted from individuals' construal of experiences and enactment of social interactions, being then multi-stratally and multi-functionally organized (Halliday, 1978, 1985, 1994; Halliday \& Matthiessen, 2004, etc.).

The meaning in language is primarily represented by two planes, a content and an expression plane, all together allow construing and enacting reality as well as informing how it is structured at levels of realizations. In the content plane, experiences and interpersonal relationships are transformed into strings of meaning (i.e., the stratum of semantics), which are in turn codified and arranged in the wording system (i.e., the stratum of lexicogrammar), both strata enable the meaning potential of language to expand. In the expression plane (i.e., meaning and form), the instantial features of language surface via the phonology and phonetics for spoken language, and graphology and graphetics for written language.

Language is also metafunctionally-ordered as it serves certain meaning functions for its users through three comprehensive types, ideational, interpersonal, and textual. The first 
metafunction deals with the representation and deconstruction of the experiential meaning of the world, and it is realized by the Transitivity System, enabling humans to express their ideas about what is going in an event, who are the participants involved, and the corresponding circumstances. The second metafunction implies the creation and negotiation of inter-subjectivity, allowing people to play different social roles and understand others' judgments, emotions, and attitudes employing the Mood (i.e., declarative, imperative, and interrogative) and Modality Systems (i.e., modal verbs). The last metafunction is accountable for arranging and presenting the ideational and interpersonal meanings as a cohesive and coherent discourse realized in the theme-rheme structure.

\subsection{Transitivity System}

As aforementioned and argued by Halliday (1985) and Halliday and Matthiessen (2004), the transitivity system portrays people's experiences via (a) abstract or general actions, verbal events, and attributes unfolded through time and communicated by verb phrases (i.e., process types); (b) participant(s), either people, objects, or abstractions, doing the acting or being acted upon and realized by a noun, noun groups, and pronouns; and (c) optional circumstances to express manner (e.g., comparison, quality, means), extent (e.g., distance, frequency, duration), location (e.g., place, time), cause (e.g., reason, purpose), contingency (e.g., concession, default, condition), accompaniment (e.g., additive, comitative), role (e.g., guise, product), matter and angle (e.g., point of view, source) and realized through prepositional and adverbial groups.

In that vein, this system represents 'who does what to whom, when, where, how, why, and for what' (see Table 1), being the main reason behind the emerging text analyses that seek to unveil the linguistic choices made by language users and deepen into their interpretations from the understanding of its ideational meaning. When applying this framework, the different process types are the cornerstone of the analysis as they allow to "translate the world of experience" (Halliday, 1994, p.107), followed by the depiction of the participants, and the identification of the circumstances. SFL proposes six different types of processes commonly found in the transitivity system of English and other languages as briefly presented below.

- Material. Process of 'doing and happening' in which a subject does something concrete or abstract to some other subject (e.g., paint, send, catch, play, make, buy, etc.). The Actor is the main participant, while the Goal and Beneficiary are optional affected participants who have either a change of status or position.

- Mental. Process of 'sensing' from the own consciousness the phenomena of the world in terms of perception, cognition, affection, and desideration (e.g., like, hate, feel, know, understand, see, etc.). The participant roles are the Senser (i.e., the conscious being) and the Phenomenon (i.e., what is sensed).

- Relational. Process of 'being' by which individuals either provide an attribute to an entity (e.g., be, sound, become, etc.) or give a value to it (e.g., signify, betoken, portray). In the attributive relational process, the participants are Carrier - Attribute, whereas, in the identifying relational process, the participants constitute the Token Value. This process type also encompasses a process of 'having' by which an entity possesses something (e.g., have, belong, is someone's) and it is enacted by the Possessor - Possessed participants. 
- Behavioral. Process of 'psychological and physiological behavior' that allows manifesting externally the internal processes that humans experience. These are halfway between material and mental processes (e.g., smile, cry, memorize, cough, dream, glare, etc.). The two participant roles are the Behaver and the Behavior.

- Verbal. Process of 'saying' through which symbolic relationships are built and represented in the form of language and materialized via diverse kinds of discourse (e.g., speak, chat, say, warn, show, complain, etc.). Its participants are the Sayer (i.e., the addresser), the Receiver (i.e., the addressee), and the verbiage (i.e., the content of what was told or informed).

- Existential. Processes of 'existing' that enable individuals to recognize the existence of entities (e.g., there is, be, occur, emerge, remain, hang, etc.). The only participant in this process is the Existent.

Table 1: Summary of the transitivity system (adapted from An introduction to functional grammar, by M. Halliday \& C. Matthiessen, 2004)

\begin{tabular}{|c|c|c|}
\hline Process types & Participant types & Examples \\
\hline $\begin{array}{l}\text { Material } \\
\text { Doing (physical action) } \\
\text { Happening }\end{array}$ & $\begin{array}{l}\text { Actor (doer) } \\
\text { Goal (affected } \\
\text { participant) } \\
\text { Beneficiary (client- } \\
\text { recipient) }\end{array}$ & $\begin{array}{l}\text { - Madonna (actor) is composing (process) her } \\
\text { new album (goal) in Los Angeles } \\
\text { (circumstance of location). } \\
\text { - } \quad \text { Madonna (actor) is composing (process). } \\
\text { - Madonna (actor) sent (process) her producer } \\
\text { (recipient) her new album (goal). }\end{array}$ \\
\hline $\begin{array}{l}\text { Mental } \\
\text { Perception } \\
\text { Cognition } \\
\text { Affection } \\
\text { Volition }\end{array}$ & $\begin{array}{l}\text { Senser - Phenomenon } \\
\text { Experiencer - } \\
\text { Recipient }\end{array}$ & $\begin{array}{l}\text { - } \quad \text { Even when Melany (senser) watched } \\
\text { (process) the video (phenomenon) for over } \\
\text { 1.00o times... (circumstance of extent). } \\
\text { I (senser) know it (phenomenon) because } \\
\text { of... (circumstance of cause). } \\
\text { - Adam (experiencer) loves (process) her } \\
\text { (recipient) very much (circumstance of } \\
\text { manner). } \\
\text { Unless (circumstance of contingency) the } \\
\text { new president (senser) wants (process) to } \\
\text { make the peace... (phenomenon). }\end{array}$ \\
\hline $\begin{array}{l}\text { Relational } \\
\text { Attributive } \\
\text { Identifying }\end{array}$ & $\begin{array}{l}\text { Carrier - Attribute } \\
\text { Possessor - Possessed } \\
\text { Token - Value }\end{array}$ & $\begin{array}{l}\text { - } \quad \text { Andrew (carrier) grew up wild (attribute). } \\
\text { Without you (circumstance of } \\
\text { accompaniment), Phillipe (possessor) } \\
\text { wouldn't have (possessed) a job (possessed). } \\
\text { - This (token) represented (process) a fortune } \\
\text { (value) in the past (circumstance of extent). }\end{array}$ \\
\hline Behavioral & Behaver - Behavior & $\begin{array}{l}\text { - Yesterday (circumstance of time), they } \\
\text { (behaver) looked at (process) each other } \\
\text { (behavior) and smiled (process). }\end{array}$ \\
\hline Verbal & $\begin{array}{l}\text { Sayer } \\
\text { Receiver } \\
\text { Verbiage }\end{array}$ & $\begin{array}{l}\text { - He (sayer) repeated (process) the same lies } \\
\text { - } \quad \text { The nurse told them (receiver) the bad news. } \\
\text { - } \quad \text { As an orphan (circumstance of role), I'm in } \\
\text { debt with you (verbiage), he said. }\end{array}$ \\
\hline Existential & Existent & - It (existent) remains (process) the same. \\
\hline
\end{tabular}




\section{Research Methodology}

The corpus selected for the present analysis comprises five poems (i.e., Footprints, The stone of water, Under the Earth, A word from Grandfather, and The teaching of the Sun) composed by the Colombian indigenous poet Fredy Chikangana. A mixed quantitative-qualitative methodical approach was applied to provide objectivity along with an in-depth understanding of the corpus, that is, an interpretation informed by the Transitivity System framework offered by SFL. In this regard, the steps considered to carry out the analysis included (1) identify the clause complexes (meaning potentials) of the poems; (2) map, categorize and calculate the processes types, participants, and circumstances found in each clause following Halliday's selection criteria (1994); and (3) interpret the extracted data.

\section{Findings}

From the transitivity analysis conducted on the five selected poems, it could be observed that the texts comprise 79 clauses - including 23 embedded clauses and, therefore, 79 process types as shown in Table 2.

Table 2: Frequency of process types

\begin{tabular}{|c|c|c|c|c|c|c|}
\hline $\begin{array}{c}\text { Poems / } \\
\text { Process } \\
\text { type }\end{array}$ & Footprints & $\begin{array}{c}\text { The stone of } \\
\text { water }\end{array}$ & $\begin{array}{l}\text { Under the } \\
\text { Earth }\end{array}$ & $\begin{array}{c}\text { The teaching } \\
\text { of the Sun }\end{array}$ & $\begin{array}{l}\text { A word from } \\
\text { Grandfather }\end{array}$ & Total (\%) \\
\hline Material & $8(53 \%)$ & $4(29 \%)$ & $4(23 \%)$ & $13(68 \%)$ & $8(57 \%)$ & $37(47 \%)$ \\
\hline Relational & $\begin{array}{c}\text { Attributive (2) } \\
\text { Identifying (1) } \\
\text { Possessive (0) } \\
\text { (20\%) }\end{array}$ & $\begin{array}{c}\text { Attributive (3) } \\
\text { Identifying } \\
\text { (0) } \\
\text { Possessive } \\
(0) \\
(21 \%)\end{array}$ & $\begin{array}{c}\text { Attributive } \\
\text { (2) } \\
\text { Identifying (3) } \\
\text { Possessive (1) } \\
(35 \%)\end{array}$ & $\begin{array}{c}\text { Attributive } \\
\text { (2) } \\
\text { Possessive } \\
(2) \\
\text { Possessive } \\
(0) \\
(21 \%) \\
\end{array}$ & $\begin{array}{c}\text { Attributive } \\
\text { (5) } \\
\text { Possessive } \\
\text { (0) } \\
\text { Possessive } \\
(0) \\
(36 \%) \\
\end{array}$ & $21(27 \%)$ \\
\hline Verbal & $1(7 \%)$ & $3(22 \%)$ & $2(12 \%)$ & $2(11 \%)$ & 0 & $8(10 \%)$ \\
\hline Behavioral & $2(13 \%)$ & $3(21 \%)$ & $1(6 \%)$ & 0 & $1(7 \%)$ & $7(9 \%)$ \\
\hline Existential & $1(7 \%)$ & 0 & $4(24 \%)$ & 0 & 0 & $5(6 \%)$ \\
\hline Mental & 0 & $1(7 \%)$ & 0 & 0 & 0 & $1(1 \%)$ \\
\hline Total & 15 & 14 & 17 & 19 & 14 & $79(100 \%)$ \\
\hline
\end{tabular}

The material processes have a higher occurrence accounting for $47 \%$ in the poems. Relational processes come a distant second with $27 \%$ of frequency. Verbal, behavioral, and existential processes have an overall representation of $10 \%, 9 \%$, and $6 \%$ correspondingly. Meanwhile, mental processes constitute merely $1 \%$. The combination of these processes with a series of nouns, noun phrases (participants), and adjuncts (circumstances) construct an indigenous contemporary narrative of resistance; these linguistic choices are displayed in Table 3. 
Table 3: Transitivity system realizations in Fredy Chikangana's poetry

\begin{tabular}{|c|c|}
\hline \multicolumn{2}{|c|}{ Realizations of Process Types } \\
\hline Material & $\begin{array}{l}\text { Positive load in semantic: llegamos bañados (we arrive bathed); palpitaba (beat); trepar } \\
\text { (climbing); hicieron brotar (made sprout); bebieron (drank); tejieron (woved); vinimos (we came); } \\
\text { florecer (to flourish); alimentándose (feeding on); cuelgan (hang); hicieron posibles (made } \\
\text { possible); lleva (leads); haz caso (listen to); pagar (to pay); entró (entered); entra (enters); pasó } \\
\text { iluminando (passed lighting); tomó (grabbed); inició (started); torcía (twisted); daba vueltas } \\
\text { (circled); da (gives); vinimos a germinar (we came to germinate); se vistió (dressed in); desciende } \\
\text { (descends). } \\
\text { Negative load in semantic: lanzaron (we were cast); detuvo (stopped); se ha despojado (has } \\
\text { stripped); no sigas (do not follow); no juegues (do not play); hace orinar (makes you pee); no nos } \\
\text { quitarán (won't take away); salieron a defenderla (came out to defend her). }\end{array}$ \\
\hline Relational & $\begin{array}{l}\text { Positive load in semantic - Identifying: somos (we are); este es (this is); fue (it was) - } \\
\text { Attributive: fui (I was); soy (I am); a ser (to be); somos (we are); se hizo (became); se fue } \\
\text { haciendo (became); es (is). } \\
\text { Negative load in semantic - Identifying: parecía (seemed); es (is) - Attributive: esa es (this is); } \\
\text { forrado (lined with) - Possessive: le queda (has left). }\end{array}$ \\
\hline Verbal & $\begin{array}{l}\text { Positive load in semantic: vamos interrogando (we are questioning); dice (our voice says; says } \\
\text { the stone); nos anuncia (announces). } \\
\text { Negative load in semantic: dirian (would say); reclamamos (we claim); dijeron (they all said); } \\
\text { nos recuerda (it reminds us). }\end{array}$ \\
\hline Behavioral & $\begin{array}{l}\text { Positive load in semantic: cantaron (they sang); cantar (to sing); cantan (they sing); danzan } \\
\text { (they dance); cantando (singing); alienta (encourage). } \\
\text { Negative load in semantic: mirando (watching). }\end{array}$ \\
\hline Existential & $\begin{array}{l}\text { Positive load in semantic: venimos (we come from); que habita (that lives); estamos (we are); } \\
\text { que está (which is). } \\
\text { Negative load in semantic: que se hizo (that became). }\end{array}$ \\
\hline Mental & Positive load in semantic: amé (I loved). \\
\hline
\end{tabular}

Realizations of Participants Types

Positive load in semantic - Actor: nosotros (we); nuestro corazón Yanakuna (our Yanakuna hearts); los Abuelos (the grandfathers); yo (me); el Sol (the Sun); un señor (a man); ella (she); la tierra (the Earth); los hombres y mujeres (men and women); él (he) - Goal: los Abuelos (the

Material Grandfathers); la sonrisa del maíz (the corn smile); la vida (life); animal de colores (colorful animal); al Abuelo (to Grandfather's); a la Abuela (to Grandmothe'sr); un perro recién mojado ( $a$ fresly wet dog); al humo (the smoke); danza ceremonial del continuo retorno (ceremonial dance of eternal return); una cabuya (cabochon); círculo del tiempo (circle of time).

Negative load in semantic - Actor: nuestros enemigos (our enemies); nada (nothing); pájaro gris (grey bird); fuego (fire) - Goal: la tierra (the land).

Positive load in semantic - Carrier: el día (the day) - Possessor: animal de colores (colorful animal).

Relational Negative load in semantic - Token: tierra para chivos (land for goats); este rincón (this corner) - Carrier: este lugar (this place); ese pájaro gris (grey bird); fuego (fire).

Positive load in semantic - Sayer: nuestra voz (our voice); la piedra (stone); los hilos de arco iris

Verbal (the rainbow threads); Abuelo (Grandfather); Abuela (Grandmother); Taita (daddy); mamita (mommy); palabra de mi corazón (word of my heart); todos (all/everybody) -incluyendo al Sol (including the Sun) - Receiver: a las piedras (the stones).

Negative load in semantic - Sayer: los doctores (the doctors); pájaro gris (grey bird); fuego (fire). Positive load in semantic - Behaver: las serpientes (the snakes); los Abuelos (Grandfathers); Behavioral nosotros (we); animal de colores (colorful animal); palabra de mi corazón (word of my heart). Negative load in semantic- Behaver: los doctores (the doctors). Positive load in semantic - Existent: nosotros (we); animal de colores (colorful animal); al verbo \begin{tabular}{ll} 
Existential & (to the verb). \\
\hline Mental & Positive load in semantic - Senser: la piedra (the stone).
\end{tabular} 


\begin{tabular}{|c|c|}
\hline \multicolumn{2}{|c|}{ Realizations of Circumstantial Adjuncts } \\
\hline Extent-Duration & $\begin{array}{l}\text { en cada momento de resistencia (in every momento of resistance) - Spatial: hasta el centro de } \\
\text { un gran espacio (to the center of a large space). }\end{array}$ \\
\hline & $\begin{array}{l}\text { del agua (from the water); los caminos agrestes (on the rough paths); esta tierra (this land); todos } \\
\text { los caminos (all the ways); orillas de un río bullicioso (along the banks of bustling river); esta orilla } \\
\text { (this shore); este cielo (this heaven); otras orillas (other shores); en mi cuerpo (in my body); a la } \\
\text { tierra (to earth); en el fondo de la tierra (at the bottom of earth); el mismo caracol del tiempo (the }\end{array}$ \\
\hline Location-Spatial & $\begin{array}{l}\text { very same snail of time); en esta tierra (on this earth); de arriba (from above); fuera de esta tierra } \\
\text { (out of this earth); de lo subterráneo (from the underground); despeñadero (cliff); en cama (in } \\
\text { bed); dentro de cuerpo (inside the body); el lugar (the place); todos los caminos de la tierra (all } \\
\text { roads of earth); a las casas (into the houses). }\end{array}$ \\
\hline Manner & $\begin{array}{l}\text { de un salto (from a jump); en silencio (silently) - Means: de Sol (the Sun); con los pies rotos por } \\
\text { el tiempo (with the feet broken by the time); en el cuerpo de los Abuelos (in grandfathers'bodies); } \\
\text { por entre las piedras (through the stones); por el techo de una casa (through the roof of a house); } \\
\text { entre su pierna (between his leg); sobre una olla de aluminio recién quemado (over a freshly } \\
\text { burned aluminum pot) - Quality: suavemente (gently). }\end{array}$ \\
\hline Temporal & $\begin{array}{l}\text { al amanecer (at dawn); en las noches (at night); hoy (today); en cada momento (at every } \\
\text { moment). }\end{array}$ \\
\hline Cause-Reason & $\begin{array}{l}\text { espantar la tristeza del destierro (scare away the sadness of exile); para seguir viviendo con la } \\
\text { memoria de los muertos (to continue living with the memory of the dead); para no olvidar el } \\
\text { origen (to not forget the origin); para ascender al encuentro del Sol (to ascend to meet the Sun); } \\
\text { para volver a empezar (to start again); para cazar (to hunt); para jugar (to play); para seguir } \\
\text { viviendo (to continue living). }\end{array}$ \\
\hline Accompaniment & junto a la tierra (next to the land); con el fuego (with the fire). \\
\hline Matter & $\begin{array}{l}\text { sobre nuestro paso por este mundo (about our passage through the world); sobre aquellos } \\
\text { secretos de la gran montaña (about those secrets of the great mountains). }\end{array}$ \\
\hline Rolo & cristal (became crystal clear). \\
\hline
\end{tabular}

\subsection{Huellas: Footprints}

An analysis of the first selected poem entitled Huellas (Chikangana, 2006) (See Table 3) shows that the author makes use of five processes (i.e., material 53\%, relational $20 \%$, behavioral $13 \%$, verbal $7 \%$, and existential $7 \%$ ) from which the material is the dominant type (see Table 2). This text describes, on the one hand, the scenario of marginalization and ostracism that the Yanakuna community has experienced as a result of the territorial confrontations with hegemonic powers (i.e., a centralized Colombian government, armed actors, and landowners), and on the other hand, portrays the great sense of resilience of the indigenous ascendants residing this landmark.

Chikangana relies mainly on material processes to enact this reality. Thus the negatively loaded verbs (e.g., we were cast; nothing stopped the flow of blood) represent the community struggle; conversely, the positively loaded verbs (e.g., our hearts beat Yanakuna; they made sprout the corn smile; they wove all the ways; etc.) depict the individuals' selfdetermination against the threat. Relational processes, attributive and identifying, along with their attributes and the cause-reason circumstances are also relevant resources for the author to present the negative effects of this conflict on their ancestral territory, which was turned into a deserted Warfield where only goats can live (e.g., that's land for goats). This spatial representation, although pejoratively attributed by the invaders (i.e., sayer and actor) to the indigenous population (i.e., actor) indirectly constitutes a positive quality, since these animals are well-known for being strong, tolerant, filial, and able to persevere any difficulty. Likewise, other circumstantial elements of spatial location (e.g., the rough roads; this land) 
and manner-means (e.g., with feet broken; in the body; through the stones; on all the roads of the earth) contribute to shaping this imagery of Yanakunas as enduring and cheerful individuals who despite the toughest times, they were motivated to keep alive their cultural heritage and reminiscence their roots as sons of the Mother Earth (i.e., Pachamama). This poem becomes a symbolic claim of space, collective territorial revindication, and preservation of the ancestral memory.

\subsection{La piedra del agua: The stone of water}

The poem named La piedra del agua (Chikangana, 1992) (See Table 3) displays five processes (i.e., material $29 \%$, relational $21 \%$, verbal $22 \%$, behavioral $21 \%$, and mental $7 \%$ ) which exhibit almost an even percentage of occurrence. The text incarnates the voice of river stone, an awake and alive eyewitness who through its stationary status has the privilege to deliver a narrative of the past and a concern for the transcendence of living beings. This testimonial attribute seems to be highly appreciated by the Yanakunas who approach this natural entity to corroborate their purpose on Earth as well as to look for a sense of solidarity based on shared experiences between them.

The author chooses to incorporate positively loaded material processes enacted by an inclusive pronoun "we" (e.g., we came; that's why we came to earth) together with circumstantial adjuncts of matter (e.g., about our passage through this world) to introduce the reasons behind the meaning of life and its hardships. Thus, in the first half of the poem, the stone is treated as a passive participant, a receiver who carefully listens to a series of existential questions posed and immediately answered by the poet himself (i.e., hypophora rhetorical device), who in turn plays the dual role of sayer and agent. It is worth noting that along the text lines, none of the participants are construed as doers or actors, which could imply that they are not in control of what may happen to them. However, in the second half of the text, the stone takes the active role of sayer and the voice of the author completely vanishes, it is time now for nature to agree on the assertions previously made by the author by relating them to its own subjective experience and present status quo (temporal circumstance). This is achieved through attributive relational processes (e.g., I was also fire; I am hit of water; to be a stone of water) that create its self-representation of evolution from a state of being fire (i.e., the Father fire, a symbol of human knowledge) to a state of becoming a piece of everlasting and solid sediment whose body is craved with the collective memory of the past.

Spatial location circumstances (e.g., the banks of a bustling river; this heaven; this shore; from another shore; in my body; next to the earth) are included by Chikangana to signal the places where these two monologues occur. These locations constitute organic sacred elements for the Yanakuna community as they are associated with the myth of origin and thus, ascribed with a character of remembrance that bears the imprints of hundreds of years of existence. Both nature and human beings, as guardians of the territory, are responsible for securing the preservation of their cultural heritage and therefore, nurse their contemporary indigenous identity. This idea of life purpose, which embodies the theme of the poem, is further reinforced by the addition of behavioral processes (e.g., if it is not to sing; snakes sing and dance) since according to the author's ancestral beliefs, the act of singing and dancing helps to defeat the feeling of forgetfulness and indifference (impersonated by the imagery of a serpent - behaver) they have experienced. 


\subsection{Bajo tierra: Under the Earth}

The next interpreted poem is called Bajo tierra (Chikangana, 2004) (See Table 3). It comprises five processes (i.e., material $23 \%$, relational $35 \%$, verbal $12 \%$, behavioral $6 \%$, and existential $4 \%$ ) from which relational verbs are predominant, followed by material and existential. The literary composition resorts mainly to processes of being (e.g., we are that colorful animal; we are the very snail of time; we are also from above) as a mechanism to bring upon to the author self-identifying values as the ones incarnated by those residing in the underground (i.e., a place for the spirits of the death) and the up world (i.e., a place for the Deities), reference points suggested by the recurring spatial location circumstances (e.g., at the bottom of the earth; from the underground; from above; out of this earth) along with the existential realizations (e.g., what is; that inhabits; that became).

This property of the text allows it to display two different but yet complementary discursive scenarios. On the one hand, in the initial eight lines of the poem, the author's inclusive poetic persona (i.e., We) introduces a detailed picture of the existential nature of himself and his community, that is, a portrayal of his identity as Yanakuna (i.e., being one with Mother Earth), an individual who embodies the legacy of his predecessors and aspires to reach almighty. Allusive references of positively loaded material and behavioral processes (e.g., feeding on its own essence; singing; where the first lichens hang; made life on this earth possible) performed by organic inanimate and animate subjects (e.g., that colorful animal; the oldest grandparents) together with a cause-reason circumstance (e.g., to ascend to meet the sun), and the inclusion of a goal participant (e.g., life) are proof of the aforesaid.

On the other hand, in the subsequent strings of the poem, Chikangana (sayer) makes a hearty claim (e.g., we claim our right) to retrieve his/their land rights and autonomous ownership as explicitly stated in the content of his verbiage (e.g., our right to the moon, to the sun, to the crystal-clear water, etc.). This sense of authority to speak on behalf of his territory results from his supernatural capability to dwell through the realms of death and the Gods, which in turn enables him to become a testimonial voice of the devastating historical events faced by his community. Consequently, as the text closes, the author once again brings back the idea of his existential presence as a Yanakuna member, but unlike its initial positive depiction, the new imagery is created as a weary and dejected subject who is only left with its inner strength, the possessive relational process (e.g., who only has left the strength of his heart) serves to enact this last representation.

\subsection{Enseñanza del Sol: Teaching of the Sun}

Another work by Chikangana is the poem Enseñanza de Sol (Chikangana, 2006). It is internally composed of three processes (i.e., material 68\%, relational $21 \%$, and verbal $11 \%$ ) being material verbs the ones commanding its general construal (See Table 3). In an attempt to keep claiming and replicating the indigenous land right demand, in this particular literary text, the Sun-deity is placed as the primary actor who, supported by the rising voices of the Yanakuna community, pleads on behalf of this claim. The verbal processes (e.g., "They will not take away the earth", they all said; it reminds us of that fight for Mother Earth) along with its participants (e.g., they all said -including the Sun-) signal this request, which in turn comprises the theme. 
The omniscient and omnipotent Sun deity is entitled to perform almost $70 \%$ of the actions depicted in the poem. This time and unlike the previously discussed poetry in which the author posited himself as the main participant, Chikangana seeks to allocate his discourse on a third entity who possesses a higher degree of authority and therefore, of acting. Hence and following a narrative tone, the poet discloses how the Sun descended to Earth to celebrate a collective ritual performance to reverse time and summon the rebirth of Mother Earth. The description of this whole scenario is realized by material processes (e.g., the Sun gently entered the roof of a house...he passed lighting the ribs of a freshly wet dog...he grabbed the smoke...and started the ceremonial dance; the Sun dressed in water), circumstantial elements of manner (e.g., gently entered the roof of a house; from a jump) and means (e.g., between his legs; over a freshly burned aluminum pot), along with goal participants (e.g., the smoke; the ceremonial dance of the continuous return; the circle of time).

During this ceremony, a voice of territorial claim is overheard in unison followed by a confident assertion of ownership and self-reaffirmation of existence as indicated by the identifying relational process (e.g., this is the place where we came to germinate), which functions to designate the 'land' as the core spatial location circumstance and subsequent actor in charge of nurturing people's lives (e.g., the land that gives the strength to continue living), beliefs and worldviews. The insertion of this latter cause-reason adjunct serves as further encouragement to mobilize participants (i.e., the Sun and the Yanakuna community) to resist the violent invasion of outsiders or non-indigenous self-proclaimed owners. This scene is illustrated in detail by the material (e.g., men and women came out to defend her; the Sun dressed in water) and attributive relational processes (e.g., it became stronger) in conjunction with its participants (e.g., men and women; the Sun) and corresponding attribute (e.g., stronger). The text ends with an intentional shift of narrator, from third to first person (i.e., the author's voice), who is expected to deliver a causative testimony of the feats and teachings of the Sun-deity and the ancestors for successors to learn and pursue.

\subsection{Palabra del Abuelo: A word from Grandfather}

The last revised poem is Palabra del Abuelo (Chikangana, 2010). It encompasses three processes (i.e., material $57 \%$, relational $36 \%$, and behavioral $7 \%$ ) with a major representation of material concrete actions (See Table 3 ) as manifestations of probable consequences if the receiver participant (i.e., the author) does not take into consideration the given pieces of advice.

On the base of this subject matter, the text unfolds in the sequential introduction of one character after the other. The first two sayers (i.e., Grandfather and Grandmother) perform the role of knowledgeable and wise advisers warning the author to be careful with some natural entities (e.g., gray bird; fire) as they are ill-omen. This cause-effect discourse is realized by the material (e.g., do not follow; do not play; it leads to the cliff; it makes you pee) and attributive relational processes (e.g., it is) along with its negatively loaded attributes (e.g., spirit; death; cold inside the body). The following sayers (i.e., Daddy -Taita- and Mommy -Mamita-), from a parenting position, corroborate the first participants' caveat and firmly demand the author to take heed of it, action processes (e.g., listen to grandfather's; listen to grandma's) and cause-reason circumstantial elements (e.g., you have to pay to hunt; you have to pay to play with fire) enact this verbiage. Lastly, the carrier participants (e.g., Gray bird; Fire), initially discredited by the grandparents, take the floor and vehemently 
counterargument their accusations by ascribing them unfavorable traits, this can be evidenced through the attributive relational processes "is" and its qualifiers (e.g., suspicious man; malicious woman).

As a closure, the author's poetic persona is brought to the scene to assert that despite the voices he has listened to, he is willing to discover by himself the mysteries of life, as it is signaled by his verbiage (e.g., word of my heart - welcome the mystery - encourage this singing.). In summary, this literary piece becomes a collective effort to evoke the image of the Yanakunas' long-standing community and its socio-cultural reality, a goal achieved through the portrayal of the family as a guiding entity, the impersonification of the memory as organic beings that bear witness of life and death, and the poet's representation as an orator whose messages are grounded on the teachings and the testimonial voices of his people.

\section{Discussion}

The literary production and distribution that do not follow the official standards of the dominant canon and the modernizing discourses is frequently made invisible for being regarded as marginal, minor, secondary, and a folkloric 'hybrid object' (Barragán, 2016; Fernández, 2009; Rodríguez, 2017) belonging to the popular culture. This is a social reality that has been and is still experienced by numerous Indo-American indigenous communities like the Yanakuna since the colonialism in the nineteenth century and the rising of the conflicts in their nations. Recentering indigenous voices, experiences, and epistemologies via a dialogue that fosters the democratization of cultural rights and the restoration of the agency is what Fredy Chikangana has attempted to achieve along with the compositions of other self-declared orators like Yenny Muruy Andoque, Leonel Lienlaf, Elicura Chihuailaf, among others, who have started the 'oralitura,' an indigenous movement of people and cultures emerging from several countries like Colombia, Mexico, Chile, Peru, etc. The oralitura has been conceived as a project of cultural, aesthetics, political, ethical, and pedagogical resignification enacted from the indigenous ancestral wisdom about the past and the present times that leads to the building of new territories around the power of the 'word' to create and preserve rather than to produce misery and oblivion (Barragán, 2016; Toro, 2014).

The text analysis of indigenous poetry constitutes then a relevant enterprise to unveil how writers participate in social activities and how the context is embedded within language by identifying patterns of meanings that lead to a particular social goal (Halliday, 1978) that otherwise may go unnoticed by the majority of the audience if not read beyond the lines. Indigenous compositions have served as epistemic conduits of their knowledge crossed by their history of unequal battles for the acknowledgment of their ancestral entitlement, respect, and their right to be heard outside their community after being systematically silenced for decades. The transitivity analysis conducted on the five selected poems written by Chikangana in which the process types, participants, and circumstances were considered to reconstruct the author's world of experience, disclosed how he portrays his Yanacuna community as one claiming space and vindication of his ancestral identity to guarantee its preservation and lasting existence. His poems showed to be highly permeated by his context of situation built upon his ancestors,' family's, and his memoirs and legacy as expressed by the lexico-grammar resources he chooses, whose meanings are primarily centered in the 
notions of defiance, memory, collective identification, and the long-standing right to land, concerns that were noticed as well by Abello (2015); Campos et al. (2018); and Ceballos (2015).

Literature on the oralitura within the American continent has also confirmed the aforementioned. The contemporary indigenous literary production and particularly, poetry for being a space of collective development (Lienlaf as cited in Franco, 2009), has been significantly shaped by a series of external factors that have impacted the status quo of the community and consequently, the poets' experiences. For example, Franco (2009) explained how the poems created by the Zapotec in Mexico and Mapuche in Chile are founded on a history of resistance that has denied their idiosyncrasy. The Mapuche poetry often tackles their community struggle of loss and recovery of their memory and language after their genocide, oppression, and intolerance at the hands of the Spanish conquerors and their nation as depicted by the Mapuche writer Elicura Chihuailaf in the poem 'Confidential message to the Chilean people,' which is "part memoir, part history and part political tract, writes of Nvtram, the art of speech linked to historical memory" (p.26).

Likewise, Sánchez et al. (2019) have observed how indigenous people employ poetry as a powerful tool of resistance in Latin America. Some of these compositions could allude to the forced displacements, the systematic killing of environmental activists, and the destruction of nature brought by the large-scale mining, agriculture, and the oil industry, just like it is reflected in the numerous verses by María Teresa Panchillo, Rayen Kvyeh, and Adriana Paredes, who have condemned the water deterioration and the extinction of native forests. Comparable with Colombia, Chile, Mexico, and some other Ibero-American countries where indigenous collectives have elevated openly their voices, Salmón (1997, as cited by Rodríguez, 2017) indicated that the construal in Bolivian's poetry has been primarily motivated by their intimate relationship with 'Mother nature,' the misuse of their image for nationalist political purposes, and their portrayal as simple objects of indigenism, circumstances that have been discursively transformed in the ongoing pursuit for resistance and remembrance.

These and other findings by numerous scholars in the fields of literature, critical theory, cultural studies, etc., appear to be consistent with the statements priorly made in this document and which resulted from the SFL analysis performed on the five poems by Chikangana. Furthermore, the contemporary society is then witnessing the emergence to the public sphere of what has been theoretically coined as the 'insurgent poetics,' a mode of subjectivation characterized by the discontinuation of the transcendental coordinates of the world and the subtraction from the identitarian labels of a nation, race, and gender (Nesbitt, 2013). According to Burdette $(2014,2019$ ) and Hill (2017), the insurgent poetics have encouraged the indigenous agency towards participating in resistance actions that allow them to speak out and reclaim their rights to represent themselves in the discursive and political realm through poetry, novels, essays, and some other literary manifestations, which in turn serve as "alternatives to hegemonic forms of knowledge tied to neoliberal, capitalistic, and Eurocentric values of progress and individualism" (Burdette, 2019, p.6).

The Yanakuna's oralituras thus become insurgent poetics that demand personal accountability and collective efforts through the vindicating act of renaming the world and reconnecting with themselves and their living memory from their epistemological 
relationality with their family, community, and the Earth (or homeland), an invaluable lifegiver and provider that retains remembrances and belonging. In this sense, the present analysis provided a theoretical-practical contribution mainly to the literature of ethnic poetry from the field of discourse analysis and Indo-American linguistics, nonetheless, it should be noted that a broader selection of poems would have shred more consistent and generalized results.

Further research is recommended on the comparative analysis of the English translated versions of Chikangana's poetry versus its Spanish and/or Quechua variant, to verify whether its transitivity system still represents the same reality as the one portrayed in the initial language of production.

\section{Conclusion}

Throughout the selected corpus, the present transitivity analysis revealed that the material processes $(47 \%)$ were the ones dominating the poet's compositions by enabling him to show the concrete and physical actions performed by his participants or that influenced them with the purpose to vividly represent the Yanakuna's lived experiences as witnesses of their past and present memory. Thus, Chikangana relied on the power of poetry to generate a sense of indigenous activism that resists and subverts his and his community's unceasing historical struggles.

\section{References}

Abello, G. (2015). La poética del agua en la poesía de Wiñay Mallki/Fredy Chikangana una aproximación a la Oralitura indígena del Macizo Colombiano [The poetics of water in the poetry of Wiñay Mallki/Fredy Chikangana an approach to the Indigenous oralitura of the Colombian Massif] [Undergraduate's thesis, Pontificia Universidad Javeriana]. https://repository.javeriana.edu.co/handle/10554/15938

Abt, T. (2008). Indigenous literature, an ambivalent question of self. In G. Habrajska (Ed.), Rozmowy o Komunikacji (pp. 171-184). Leksem.

Ahenakew, C. (2016). Grafting indigenous ways of knowing onto non-indigenous ways of being. International Review of Qualitative Research, 9(3), 323-340.

Barragán, L. (2016). Palabra de los bordes que transita a través: la oralitura como posible apertura político-cultural [Word of the edges that travels through: Oralitura as a possible political-cultural opening]. Catedral Tomada. Revista de Crítica Literaria Latinoamericana, 4(7), 339-361. https://doi.org/10.5195/ct/2016.146

Boer, N., Callegaro, E., Bittencourt, C., \& Santos, D. (2018). Literature, theater and environmental education: Perspectives by the transitivity system in the poem Cora coralina, quem é você? IOSR Journal of Research \& Method in Education (IOSR-JRME), 8(4), 28-36. https://doi.org/10.9790/7388-0804042836

Burdette, H. (2014). Literary contraband: Indigenous insurgency and the spatial politics of resistance. Revista Canadiense de Estudios Hispánicos, 39(1), 273-301.

Burdette, H. (2019). Revealing rebellion in Abiayala. In H. Burdette (Ed.), Revealing rebellion in Abiayala. University of Arizona Press. https://doi.org/10.2307/j.ctvd7w887

Camelo, S. (2017). Poéticas indígenas de resistencia y reconstrucción plural de comunidad 
[Indigenous poetics of resistance and plural community reconstruction]. Nómadas, 46, 111-127.

Campos, L., Cárdenas, J., Ardila, G., \& Galeano, S. (2018). Ergoletrías. Revista Ergoletrías, 5, 36-44. http://revistas.ut.edu.co/index.php/ergoletrias/article/view/1454

Ceballos, F. (2015). Fredy Chikangana, poesía, mito y negociación [Fredy Chikangana, poetry, myth and negotiation] [Master's thesis, Pontificia Universidad Javeriana]. https://repository.javeriana.edu.co/handle/10554/17052

Chikangana, F. (1992). La piedra del agua [The stone of water]. Colibrí de la noche desnuda [Naked night hummingbird]. Fundación Sol y Serpiente de América.

Chikangana, F. (2004). Bajo tierra [Under the Earth].

Chikangana, F. (2006). Enseñanza del Sol [Teachings of the Sun].

Chikangana, F. (2006). Huellas [Footprints].

Chikangana, F. (2010). Palabra del abuelo / Shimi machupay [A word from Grandfather]. Espíritu de pájaro en pozos del ensueño [Bird spirit in dreamwells], 50-51. Ministerio de Cultura.

Damanik, E. (2018). An analysis of experiential meaning in poetry "William Wordsworth". Loquen: English Studies Journal, 10(2), 94. https://doi.org/10.32678/loquen.v1oi2.695

Fernández, C. (2009). Poesía "indígena" contemporánea y gestión cultural [Contemporary "indigenous" poetry and cultural management]. Sibila. Revista de Poesia e Crítica Literária. https://sibila.com.br/mapa-da-lingua/poesia-qindigenaq-contemporanea-ygestion-cultural/2747

Ferreira, A. (2018). Estercilia Simanca: A writer who makes the desert blossom by Ana María Ferreira. Latin American Literature Today. http://www.latinamericanliteraturetoday.org/en/2018/august/estercilia-simancawriter-who-makes-desert-blossom-ana-maría-ferreira

Franco, J. (2009). Overcoming colonialism: Writing in indigenous languages. Latin American Studies Association Forum, 40(1), 24-27.

Halliday, M. (1978). Language as social semiotic: The social interpretation of language and meaning. University Park Press.

Halliday, M. (1985). An introduction to functional grammar. E. Arnold.

Halliday, M. (1994). An introduction to functional grammar. E. Arnold.

Halliday, M. \& Matthiessen, C. (2004). An introduction to functional grammar. Hodder Arnold. Hasan, R. (1985). Linguistics, language, and verbal art. Deakin University Press.

Hassanpour, F., \& Hashim, R. (2012a). Reading Forough Farrokhzad's poetry from the perspective of systemic functional linguistics. GEMA Online Journal of Language Studies, 12(3), 923-937. http://ejournal.ukm.my/gema/article/view/1065/965

Hassanpour, F., \& Hashim, R. (2012b). An angry language: A stylistic study of the images of men in the Sylvia Plath's "Daddy." Studies in Literature and Language, 4(1), 123-128. https://doi.org/10.3968/n

Hill, M. (2017). The revolution will be social and poetic: The insurgent poetics of decolonial thought [Master's thesis, The University of Western Ontario]. https://ir.lib.uwo.ca/etd/5018

Hughes, J. (2007). Poetry: A powerful medium for literacy and technology development. What Works? Research into Practice. http://faculty.uoit.ca/hughes/Research/

Larbaoui, M. (2019). Exploring the theme of cultural identity in the poem "Song of Lawino": The use of Halliday's transitivity in revealing ideologies. Advances in Language and 
Literary Studies, 10(6), 20-24. https://doi.org/10.7575/aiac.alls.v.10n.6p.20

Nesbitt, N. (2013). Conclusion. In N. Nesbitt (Ed.), Caribbean Critique: Antillean Critical Theory from Toussaint to Glissant (pp. 271-287). Liverpool University Press. https://doi.org/10.2307/j.ctt5vjnb3.18

Ogungbemi, D. (2016). The ideological square and transitivity in the poetry of Remi Raji Oyelade. Journal of Linguistics and Language in Education, 10(2), 14-32. https://journals.udsm.ac.tz/index.php/jlle/article/view/1293/1178

Peskin, J. (1998). Constructing meaning when reading poetry: An expert-novice study. Cognition and Instruction, 16(3), 235-263. https://doi.org/10.2307/3233645

Rocha, M. (2013). Oralituras y literaturas indígenas en Colombia: de la constitución de 1991 a la ley de lenguas de 2010 [Oralituras and indigenous literature in Colombia: From the 1991 constitution to the 2010 language law]. A Contracorriente: Revista de Historia Social y Literatura En América Latina, 10(3), 74-107.

Rodríguez, K. (2019). Wiñay Mallki: Un reencuentro con la vida y la muerte [Wiñay Mallki: A reunion with life and death]. El Espectador. https://www.elespectador.com/noticias/noticias-de-cultura/winay-mallki-unreencuentro-con-la-vida-y-la-muerte-articulo-695935

Rodríguez, M. (2017). Dinámicas de contacto entre la producción poética andina (kichwa y aymara) y el canon literario [Dynamics of contact between Andean poetic production (Kichwa and Aymara) and the literary canon]. Letras, 88(127), 32-54.

Sánchez, J., Echeverría, A., \& Zevallos-Aguilar, U. (2019). La cosecha honorable [The honorable harvest.]. Diálogo, 22(1), 3-5. https://doi.org/10.1353/dlg.2019.0001

Sims, E., \& Lea, V. (2008). Transforming whiteness through poetry: Engaging the emotions and invoking the spirit. Counterpoints, 321, 67-77. www.jstor.org/stable/42979959

Toro, H. (2014). Oralitura y tradición oral: una propuesta de análisis de las formas artísticas orales [Oralitura and oral tradition: A proposal for the analysis of oral artistic forms]. Lingüística y Literatura, 65, 239-256.

Zuhud, A., \& Afrianto. (2014). Mental and relational process of transitivity in Donne's and Blake's poems: A systemic functional linguistics approach. International Journal of English and Education, 3(2), 9. 